\title{
Correction: Johnes, P.J.; et al. Determining the Impact of Riparian Wetlands on Nutrient Cycling, Storage and Export in Permeable Agricultural Catchments. Water 2020, 12, 167
}

\author{
Penny J. Johnes ${ }^{1, *(1)}$, Daren C. Gooddy ${ }^{2}$, Timothy H. E. Heaton ${ }^{3}$, Andrew Binley ${ }^{4}$, \\ Michael P. Kennedy ${ }^{5}$, Paul Shand ${ }^{6}$ and Hannah Prior ${ }^{7}$ \\ 1 School of Geographical Sciences, University of Bristol, Bristol BS8 1SS, UK \\ British Geological Survey, Maclean Building, Wallingford, Oxfordshire OX10 8BB, UK; dcg@bgs.ac.uk \\ 3 NERC Isotope Geosciences Laboratory, British Geological Survey, Keyworth, Nottingham NG12 5GG, UK; \\ theh@nigl.nerc.ac.uk \\ 4 Lancaster Environment Centre, Lancaster University, Bailrigg, Lancaster LA1 4YQ, UK; a.binley@lancaster.ac.uk \\ 5 School of Energy, Construction and Environment, Coventry University, Priory Street, Coventry CV1 5FB, UK; \\ michael.kennedy@coventry.ac.uk \\ 6 College of Science and Engineering, School of the Environment, Flinders University, PO Box 2100, \\ Adelaide SA 5001, Australia; paul.shand@flinders.edu.au \\ 7 Smith School of Enterprise and the Environment, University of Oxford, Oxford OX1 3QY, UK; \\ hannah.prior@smithschool.ox.ac.uk \\ * Correspondence: pj13302@bristol.ac.uk
}

Received: 5 April 2020; Accepted: 7 April 2020; Published: 28 June 2020

The authors wish to make the following corrections to this paper [1]:

Please replace Funding section with the funding below:

Funding: This research was funded under the NERC DOMAINE programme (NE/K010689/1); NERC LOCAR programme (NER/F3/G13/17/41; NER/T/S/2001/00942), jointly funded by the Environment Agency); a NERC Isotope Geoscience Facility grant (NER/IP/779/0902); and a NERC studentship for Hannah Prior (GT4/94/402), jointly funded by English Nature. We also acknowledge the immense field support from Nigel Crook, supported under a NERC LOCAR grant NER/T/S/2001/00948, and Heather Musgrave, funded through a further NERC studentship NER/S/A/2003/11344.

The authors would like to apologize for any inconvenience caused to the readers by the change. The change does not affect the scientific results. The manuscript will be updated and the original will remain online on the article webpage, with a reference to this correction.

\section{Reference}

1. Johnes, P.J.; Gooddy, D.C.; Heaton, T.H.E.; Binley, A.; Kennedy, M.P.; Shand, P.; Prior, H. Determining the Impact of Riparian Wetlands on Nutrient Cycling, Storage and Export in Permeable Agricultural Catchments. Water 2020, 12, 167. [CrossRef]

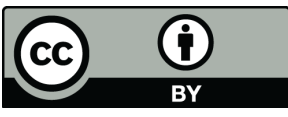

(C) 2020 by the authors. Licensee MDPI, Basel, Switzerland. This article is an open access article distributed under the terms and conditions of the Creative Commons Attribution (CC BY) license (http://creativecommons.org/licenses/by/4.0/). 